\title{
THE LEGAL SYSTEM AND THE NATIONAL DEFENSE SYSTEM. REPORTS AND FUNCTIONALITY
}

\author{
Colonel Marius POPESCU ${ }^{117}$
}

\begin{abstract}
Within any legal system, implicitly also in the national one, the Constitution stands out as important, a fundamental law that represents the supreme system of political-legal norms. Article 118 para. 2 of the The Constitution of Romania states that "The structure of the national defense system, the preparation of the population, economy and territory for defense, as well as the status of military personnel, are established by organic law" and, in light of the above regulation, the headquarters of the matter regarding the national defense system is represented by Law no. 45/1994 of the national defense of Romania, with the subsequent modifications and completions, this being established, at art. 6, the fact that the national defense system includes: leadership, forces, resources and territorial infrastructure. On the other hand, collaboration with partners or allies within NATO or strategic partnerships is an essential component of national and regional security.

Thus, the participation of the armed forces in missions and operations outside the territory of the Romanian state, the entry, stationing, conduct of operations or transit of Romanian territory by foreign armed forces, or Romania's participation in the Missile Defense System, are legally substantiated issues. on a complex set of normative acts which, through their interpenetration, through the existing relations between them, manage to create a true pillar of the national and collective defense.
\end{abstract}

Keywords: national defense system; Supreme Council of National Defense; defense planning.

Globally, defense threats, challenges and risks, the dangers cause the states of the world to pay, as is natural, a special attention to national defense. It is easy to imagine that a state with a modest defense capacity is a state that is, so to speak, at the mercy of other states, terrorist organizations or other actors that are often not well-intentioned (e.g., transnational networks). who practice illicit trafficking, organized crime etc.),

Thus, in the case of medium-sized countries, in general none of them will be able to establish a lasting hegemony over all the others, largely because they will unite, forming alliances, against it. In other words, alliances arise from states' attempts to maintain a balance of power between them.

For example, the creation of alliances as a method of maintaining balance, as a way of maintaining peace, was adopted in fifteenth-century Italy and later

\footnotetext{
${ }^{117}$ Colonel Marius Popescu is Head of International Law and Legal Affairs Office within General Legal Directorate / ROU MoND. Col. Popescu previously served as Military Expert at the United Nations Office of the Special Coordinator on Improving the UN response to Sexual Exploitation and Abuse at the UN Headquarter, New York (2016-2018).
} 
extended to the whole of Europe. With the help of this system, the aim was to limit the two great dangers that threatened, at that time, the sovereignty of the states: the extension of the Ottoman domination and the increase of the power of the Habsburgs. In this way, in order to cope with the French invasion of Italy, the King of Spain, the Pope, Venice, Milan and Emperor Maximilian I united in the League of Venice.

Thucydides, in the fifth century BC, argued that nations entered into alliances to discourage or go to war out of "honor, fear, and interest."

In the contemporary era, in general, the existence of a threat to a state from a hostile power is a necessary (and, in most cases, sufficient) condition for the development of a security alliance. In this context, a military alliance is an international agreement on national security, in which the contracting parties agree on mutual protection and support in the event of a previously unidentified crisis. It is important to note that military alliances differ from coalitions, the latter being formed in order to resolve an already existing crisis. As is well known, the identity of common values, security interests, principles of state organization and functioning, a not very high level of economic and military power, limited availability of essential resources, or other elements important for the proper functioning of A state is a factor that facilitates, in turn, bringing states together, usually in regional alliances, for better and more integrated management of defense efforts.

The Charter of the United Nations, through Article 51, introduces the legitimacy of individual and / or collective defense: "Nothing in this Charter shall affect the natural right of defense, individual or collective, where a member of the United Nations is the object of armed aggression, until the Security Council has taken the necessary measures to maintain international peace and security".

Subsequently, these provisions were supplemented. Thus, in art. 1 of Resolution no. 3314/1974, the circumstances necessary to define the right to selfdefense of states were specified: "Aggression is the use of force by a state against the sovereignty, territorial integrity or political independence of another state or in any manner incompatible with the Charter of the United Nations. of this definition". Legitimate collective defense consists in the right, for a state not directly attacked, to intervene on behalf of the defense agreements concluded with the attacked state. This principle was the basis for the formation of the international military coalition that launched, in March 2003, the military operation in Iraq, in which Romania also participated. ${ }^{118}$

According to this mechanism, also in the case of Romania, the efforts directed in the direction of national defense are made permanently considering that this can be achieved, in the optimal way, within the collective defense of

\footnotetext{
118 Dr. Constantin Moştoflei, dr. Petre Duțu, Național și colectiv în apărarea României, Editura Universităţii
} Naţionale de Apărare „Carol I” Bucureşti, 2007. 
NATO. In this sense, the adopted strategies, the endowment of the Romanian Army with means of combat and armament, the training and improvement of military and civilian personnel are made according to NATO standards and plans, as a politico-military institution within which it is conceived, organized and put into practice where necessary, the collective defense of the Member States.

\section{GENERAL LEGISLATIVE FRAMEWORK OF THE NATIONAL DEFENSE SYSTEM}

Within any legal system, the Constitution stands out as important, which represents the supreme system of politico-legal norms, the fundamental law of the state, having at the same time a superior legal force as a normative act, thus creating a hierarchy of normative acts: constitution, organic law, ordinary law, etc.

Through its legal norms, the legal system imposes itself on all social systems, disciplining them and imposing certain rules of operation on them; in this way, it contributes to the performance of the company's management function; he is, as has been well pointed out in the doctrine, the constitutive, main and most important element of the management of society.

Similarly, at the national level, the entire legal base of the matter regarding the national defense system is found in the Constitution of Romania, republished ${ }^{119}$ which, at art. 118 para. 2, states that "The structure of the national defense system, the preparation of the population, the economy and the territory for defense, as well as the status of military personnel, are established by organic law."

Thus, in light of the above-mentioned regulation, Law no. 45/1994 of the national defense of Romania, with the subsequent modifications and completions, represents the main legislative act of the matter in the field subject to analysis, and it states, at art. 6, the fact that the national defense system includes: leadership, forces, resources and territorial infrastructure.

According to art. 7 of the same normative act "the management of the national defense system is an exclusive and inalienable attribute of the constitutional authorities of the state and is achieved by: Parliament, President of Romania, Supreme Council of National Defense, Government of Romania, Ministry of National Defense and public administration authorities with responsibilities in the field of national defense. "

\subsection{The National Defense of Romania}

According to Law no. 45/1994 of the national defense of Romania, the national defense system includes: the leadership, the forces, the resources and the territorial infrastructure. The armed forces include the army, large units and units

119 Constituția României, republicată, https://www.ccr.ro/wp-content/uploads/2020/03/Constitutia-2003.pdf, accessed 15.05.2021. 
subordinated to the Ministry of Internal Affairs, those of the state intelligence services and other armed defense formations organized according to the law.

The army is subordinated exclusively to the will of the people. This subordination aims to guarantee the sovereignty, independence and unity of the state, the territorial integrity of the country, as well as constitutional democracy.

Defense planning and national defense strategy, as an attribute and essential component of defense policy, is a complex of activities and measures aimed at protecting and promoting national interests, defining and meeting Romania's national security objectives in this area.

Its legal basis is found in Law no. 203/2015, being defined as the process underlying the transformation and modernization in the field of defense, which includes all programs, actions and measures initiated by Romania to identify, develop and prepare military and non-military capabilities necessary to fulfill missions and objectives in the field of defense for:

a) the fulfillment of the obligations deriving from the Constitution of Romania, republished, and from the law, as well as from those incumbents on Romania in ensuring the security and collective defense within NATO;

c) ensuring Romania's participation in the European Union's Common Security and Defense Policy;

d) compliance with the commitments in the context of international cooperation in the field of defense with other states and the fulfillment of obligations assumed by participating in the activity of other international organizations or in other situations regulated by international law, in accordance with the law.

In order to fulfill its missions, objectives and commitments, Romania develops and maintains a unique set of capabilities, managed through an integrated defense planning mechanism. Coordination of the defense planning process is a basic element of the process of democratic civil control in the field of defense.

\subsection{National Defense Strategy 120}

According to art. 4 of Law no. 203/2015, the National Defense Strategy of the Country (NDSC) is the basic document that substantiates the defense planning at national level.

The President of Romania, within maximum 6 months from the date of taking the oath, presents in the Parliament the National Strategy for the defense of the country which is debated and approved, by decision, in a joint meeting of the two Chambers.

Through its objectives and content, this document refers to the defense of the country and national security as a whole. The paradigm shifts regarding the

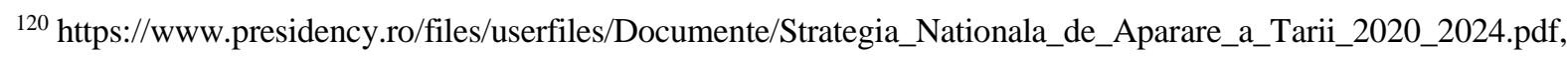
accessed at 8 May 2021, 19: 30.
} 
concept of country defense and national security, related to the increasingly unpredictable dynamics of the security environment.

In general, the National Defense Strategy reflects the need to promote a concept of extended national security, based on constitutional democracy and mutual respect between citizens and the state, which aims at interests that converge to ensure national security, manifested in the following areas: defense (understood in double normative quality, national defense and collective defense), public order, information activity, counter-intelligence and security, education, health, economic, energy, financial, environment, critical infrastructures.

It has an integrative and multidimensional approach, in which the defense dimension merges and balances each other with a number of other dimensions: public order; the activity of information, counter-intelligence and security; diplomacy; managing their crisis situations; education, health and demography.

The need to extend the concept of national security is also motivated by ensuring convergence with European security principles, developed in the European Security Strategy and the European Union's Internal Security Strategy, in which security and development are placed in a directly proportional relationship.

In addition, the extension of the concept of national security aims to ensure greater resilience of state institutions and civil society in the face of possible crisis situations, fortuitous or persistent, in an unpredictable international security environment and in a complex security context.

\subsection{White Paper of Defense ${ }^{121}$}

This document is elaborated by the Ministry of National Defense for fulfilling the provisions of the National Strategy for National Defense and implementing the defense objectives established by the Government Program, in accordance with the provisions of Law no. 203/2015 on defense planning.

\subsection{The Supreme Council of Defense of the Country}

The existence of a politico-military body with responsibilities in the field of defense of the country represents a tradition that has its source in the period between the two world wars.

After the completion of the national unity on December 1, 1918, the Romanian unitary state underwent a period of profound and complex political transformations whose expression was found in the adoption of the Constitution of 1923, appreciated at that time, among the most modern in Europe. In this Constitution, at art. 122, it was provided that: "A Superior Council of National Defense will be established which will take care, permanently, of the necessary measures for the organization of national defense".

\footnotetext{
${ }^{121}$ https://sgg.gov.ro/1/wp-content/uploads/2021/03/CARTA-ALBA-A-APARARII-.pdf, accesed at 8 May 2021, 20: 10 .
} 
Thus, on March 14, 1924, the Law on the organization of the Superior Council of National Defense was adopted, which was meant to "examine, coordinate and solve all issues related to national defense." The decisions of this forum were binding after their acceptance by the Council of Ministers.

Under the communist regime, a decision to establish the Defense Council of the Socialist Republic of Romania was determined by the events in Czechoslovakia in August 1968.

In this context, the Great National Assembly adopted, on March 14, 1969, Law no. 5 for the establishment, organization and functioning of the Defense Council of the Socialist Republic of Romania.

Regarding the purpose of creating the Council, art. 1 stipulates: "The Defense Council of the Socialist Republic of Romania is established, a deliberative body, which has the task of examining, coordinating and solving the main problems in the field of defending the country and ensuring state security both in time of peace and in time of war."

The Council shall be convened only by its chairman at least twice a year and shall decide by an open majority vote of its members. The new structure was not a legislative body. The Council discussed a series of decisions which were subsequently adopted, depending on the specifics, by: The President, the Council of Ministers or the Grand National Assembly.

After December 1989, the events that took place throughout 1990 forced the state institutions to re-establish, by Law no. 39/1990, a Defense Council under the name of the Supreme Council of National Defense - with broad attributions (which include provisions from both previous normative acts). However, this regulation appeared at a time when the new Constitution was not adopted.

Law no. 415/2002 ${ }^{122}$, developing the constitutional provisions, establishes over 28 attributions of the Supreme Council of National Defense, summarized in the annual reports of this body, on 12 main directions of action, as follows:

- approval of documents of a political nature, of strategic importance (national security strategy, national defense strategy) and its activity reports;

- coordinating the activity of the institutions of the national security system for consolidating Romania's role within the North Atlantic Alliance, the European Union and the other international organizations;

- supervising the activity of defense and public order (the fight against corruption, fraud and money laundering, prevention and combating of smuggling, illegal migration and trafficking in human beings, trafficking and illicit drug and drug use);

- unitary coordination of information, counter-intelligence and security activity. Measures to strengthen national security;

- approval of draft normative acts;

\footnotetext{
${ }^{122}$ https://csat.presidency.ro/ro/prima-pagina/legea-de-organizare, accessed at 9 May 2021, 16: 10.
} 
- ensuring the resources and infrastructure necessary for the defense of public order and national security;

- supervising the preparation of the economy and the mobilization reserve for defense;

- analysis of the protection of national, NATO and EU classified information, as well as those that are the subject of agreements;

- civil emergency management (global climate change, extreme weather events);

- ensuring energy security;

- appointments and promotion, participation in the exam for the rank of general, as well as some aspects of social protection of the military. The President of Romania fulfills within the Supreme Council of National Defense.

In the analysis of the phrase the Supreme Council of National Defense (autonomous administrative authority), the category of autonomous authority must be clarified first of all (neither the regulations in force nor the doctrine in the field have clarified this notion).

Thus, a first meaning concerns the autonomy (independence) of this authority from the state powers (if it is an autonomous administrative authority, the autonomy (independence) is manifested only towards the Government).

Another meaning, which refers only to the autonomous administrative authorities, refers to financial autonomy, the respective authority having the obligation to self-finance, but remaining under the subordination or direct coordination of the Government or a ministry.

However, the Supreme Council of National Defense cannot be included in any of these meanings. Also, although at a first evaluation of the directions of action of the Supreme Council of National Defense, it would seem that they have only an administrative character, analyzing the decisions of this forum, we find that most of them have a political character.

It could be said that the role of the Supreme Council of National Defense increases exponentially, depending on the aggravation of the situation, during exceptional situations. Thus, it can be said that starting with the establishment state of siege, the Supreme Council of National Defense practically shares power with the Government, under certain conditions.

According to the provisions of the approved mobilization plan, the Ministry of Public Finance elaborates the draft state budget for war, based on the proposals of the ministries and of the other institutions with attributions in case of mobilization or war. The implementation of the mobilization plan and the execution of the state budget for war is approved by the Parliament, based on the proposals of the Supreme Council of National Defense.

Law no. 45/1994 on the national defense of Romania, with subsequent amendments and completions, regulates, mainly, the actions carried out by the 
decision-makers after the declaration of the state of war (the regime of requisitions, the establishment of the General Headquarters, directly subordinated to the Supreme Defense Council, the regime of obligatory provision of some services by the population, the regime of the county military commands, etc.).

In view of the arguments presented, we consider that the Supreme Council of National Defense is a public authority of the executive branch. In this context, the executive power, in the case of Romania, would be composed of: President, Government and the Supreme Council of National Defense.

The Supreme Council of National Defense ${ }^{123}$ is a public authority and its secretariat, according to art. 11 of Law no. 415/2002, operates within the Presidential Administration, being coordinated by the secretary of the Supreme Council of National Defense.

The Supreme Council of National Defense does not have a permanent activity, as it has the institution of the head of state or the Government, but is convened by its president, quarterly or whenever necessary. It is true that the Government also meets weekly or whenever it is needed, but when it does not meet, the continuity of functioning is ensured by the Prime Minister and the specialized apparatus of the Government. In the case of the Supreme Council of National Defense (collegiate leadership structure) the prerogatives of the president can be manifested only in its plenary.

In the exercise of its attributions, the Supreme Council of National Defense issues decisions, according to the law, which are binding for the public administration authorities and the public institutions to which they refer. They are responsible, in accordance with the law, for the measures taken to implement them.

The decisions of the Supreme Council of National Defense are signed by its president and are communicated to the public administration authorities and public institutions to which they refer, in full or in extract, except for those for which it is decided otherwise. As a rule, these decisions (as in the formulas of the interwar constitutions or from the communist regime) must be validated by decisions of the Romanian Parliament or, as the case may be, implemented by Government decisions, in order to have legal force.

\section{LEGAL ASPECTS REGARDING THE PRESENCE OF FOREIGN ARMED FORCES ON THE TERRITORY OF ROMANIA}

\subsection{General legal framework of the presence of foreign armed forces on the territory of Romania}

The legal basis regarding the conditions under which the foreign armed forces may enter, station, carry out operations or transit the territory of Romania

\footnotetext{
${ }^{123}$ https://csat.presidency.ro/ro/prima-pagina/componenta-csat, accessed at 9 May 2021, 17: 00.
} 
is provided by Law no. 291/2007 on the entry, stationing, conduct of operations or transit of foreign armed forces on the territory of Romania. ${ }^{124}$

In accordance with art. 1 para. (2) of the mentioned law, its provisions shall be applied insofar as the treaties ratified by the Romanian Parliament do not provide otherwise. This provision resumes the thesis of art. 11 of the Constitution of Romania according to which "The Romanian State undertakes to comply just as in good faith its obligations under the treaties to which it is a party. The treaties ratified by the Parliament, according to the law, are part of the internal law ".

Adoption of Law no. 291/2007 fulfilled a requirement of art. 118 paragraph 5 of The Constitution of Romania, according to which: "On the territory of Romania may enter, station, carry out operations or pass foreign troops only under the conditions of the law or international treaties to which Romania is a party".

This solution was imposed, first of all, due to the fact that the Romanian legislation in the matter, in force until the adoption of Law no. 291/2007, did not make a clear distinction between the legal status of forces belonging to NATO Member States or those participating in the PfP (status governed by the NATO SOFA Agreement and the PfP SOFA Agreement, concluded in 1995) and the legal status of the armed forces of other states and, secondly, because, although a member of the North Atlantic Alliance, Romania maintains its military relations with other states, relations that can materialize in the conduct of joint exercises on the territory of the Romanian state.

For this category of armed forces, the normative act provides minimum requirements that must be observed when entering, transiting or stationing on the territory of the Romanian state. On the basis of reciprocity, according to the technical agreements concluded by the Ministry of National Defense, certain facilities are provided to ensure the proper conduct of activities.

The provisions of the Treaties on the Status of Forces apply to the armed forces belonging to NATO member states or to the PfP, and in the situation where they do not have or refer to national legislation, the provisions of Law no. 291/2007.

On the other hand, the provisions of Law no. 291/2007 also apply in cases where the agreements on the legal status of the armed forces belonging to NATO Member States or those participating in the PfP do not provide for certain situations or refer to the relevant national legislation. For the implementation of its provisions, as well as of the treaties regarding the status of the foreign armed forces on the Romanian territory, Law no. 291/2007 provides for the establishment of an inter-ministerial commission for liaison with foreign armed forces. The Commission ensures the coordination of the activities of the

\footnotetext{
124 https://dpap.mapn.ro/app/webroot/fileslib/upload/files/Cooperare\%20militara\%20-\%20legi/Legea_291-
} 2007.pdf, accessed at 12 May 2021, 17: 30. 
Romanian public authorities in order to solve all the practical aspects that may be encountered in the relations with the foreign armed forces located on the Romanian territory. The Commission is usually composed of representatives of institutions whose fields of activity are in the field of stationing foreign armed forces in Romania, namely the Ministry of National Defense, the Ministry of Finance, the Ministry of Foreign Affairs, the Ministry of Internal Affairs, as well as representatives of other public institutions (depending on the situations submitted for analysis).

As a whole, Law no. 291/2007 contains provisions regarding:

- the procedure for approving the entry of foreign armed forces on the Romanian territory;

- conditions regarding the entry or exit of members of foreign armed forces in / from Romania;

- movement of vehicles, ships and aircraft;

- rules on weapons, equipment and combat equipment;

- establishing the general framework for regulating the activities regarding the electronic communications networks and services and the regime of authorization of these activities;

- public medical and health care;

- observance of the environmental protection rules by the members of the foreign armed forces during the presence on the Romanian territory;

- the conditions and modalities regarding the employment of the local labor force by the foreign armed forces;

- the procedure for settling the claims for damages caused by the members of the foreign armed forces during the presence on the Romanian territory;

- exercising the right of jurisdiction over the members of the foreign armed forces while they are on the Romanian territory.

Regarding the exercise of the right of jurisdiction over the members of the foreign armed forces, the provisions of Law no. 291/2007 distinguish that, while they are on the territory of Romania, they are obliged to respect the Romanian legislation, as well as the generally recognized principles of international law.

\subsection{Legal framework of the presence of the NATO member forces in Romania. NATO SOFA TREATY}

Following the accession to the North Atlantic Treaty in 2004, in order to regulate both the status of the armed forces of the Member States during their activities on the territory of Romania and during their activities on the territory of another Member State, Romania acceded to the NATO Agreement. SOFA by Law no. 362/2004. 
The NATO SOFA ${ }^{125}$ agreement regulates the status, rights and obligations of the armed forces and the civilian component of a NATO state when operating in the territory of another NATO member state.

According to NATO SOFA ${ }^{126}$, on the territory of the receiving state (the state where they are stationed or in transit), members of the armed forces, their civilian component and their family members are obliged to comply with the national law of that state and to refrain from any activities that could prejudice the purposes of the agreement.

Of particular importance in NATO SOFA is Article VII, which regulates the exercise of criminal and disciplinary jurisdiction over members of the force, the civilian component and their family members. Thus, the military authorities of the sending State shall exercise, in the territory of the receiving State, criminal and disciplinary jurisdiction over persons who are subject to the military laws of that State. On the other hand, the military authorities of the receiving State shall exercise jurisdiction for offenses committed by members of the armed forces of the sending State or its civilian component in respect of offenses committed in the territory of that State and criminal offenses under its criminal law and also for offenses committed by the members of their family.

Also, art. VII regulates in detail the rules applicable to the exercise of the exclusive right of jurisdiction of the sending State in the event of a competition of jurisdictions. The minimum rights and guarantees enjoyed by persons prosecuted before the courts of the receiving State shall be provided, as well as the cooperation between the two States in order to ensure the proper administration of justice.

Article VIII, in the same document, refers to the way of resolving claims resulting from damage to property of the contracting parties or third parties, respectively injury or death of persons, as a consequence of the activities of members of the force on the territory of the receiving State.

Thus, the conditions under which the receiving State waives any claims for damages caused to property used by its armed forces are regulated. The sending State shall also waive all claims on any other NATO Member State, resulting in the injury or death of any member of its armed forces, while such a member has acted in the performance of his official duties.

With regard to the claims of third parties determined by actions taken by members of the force or civilian component in the exercise of its official duties or by any other act or circumstance for which the force or civilian component is responsible, the receiving State is obliged to resolve according to its own law. Compensation due to a third party, regardless of whether they are agreed upon

\footnotetext{
125 https://dpap.mapn.ro/app/webroot/fileslib/upload/files/Cooperare\%20militara\%20-\%20legi/Legea_3622004.pdf, accessed at 14 May 2021, 18:30.

${ }^{126}$ Marian Drăguț, Drept internațional. Statutul juridic al forțelor armate străine pe teritoriul României, Editura C.H. Beck, Bucureşti, 2009.
} 
amicable or established by a court decision, are paid by the receiving state, and part of the amount of this compensation will be reimbursed by the responsible state or states.

Another category of claims is those caused by damages caused to other categories of goods, a situation in which the procedure for resolving claims by a sole arbitrator is provided.

The NATO SOFA Agreement also contains provisions on the documents on the basis of which the entry of forces into the territory of the receiving State, the procedure for purchasing goods and services on the territory of the receiving State, customs regulations, exemptions from taxes and duties granted to the force, civilian component and their members., including their family members. According to art. IX para. (1), members of a force or civilian component and their family members may purchase goods locally, which are necessary for their own consumption, and may use the services they need, under the same conditions as nationals of the receiving State. Also, according to para. (2), the goods on the local market necessary for the subsistence of a force or a civilian component will normally be purchased through the competent services which procure such goods for the armed forces of the receiving State. In order to avoid such acquisitions having a negative effect on the economy of the receiving State, the competent authorities of that State shall, where necessary, determine the goods the purchase of which must be restricted or prohibited.

Article XVI establishes the competence of the North Atlantic Council to intervene in the settlement of disputes concerning the interpretation and application of the Agreement, which could not be resolved through direct negotiations between the parties concerned.

\subsection{Legal framework of the presence of the United States of America Forces in Romania}

The right of stationing of US forces on the territory of our country was granted based on the Agreement between Romania and the United States of America on the activities of United States forces stationed in Romania ${ }^{127}$, signed in Bucharest on December 6, 2005, ratified by Law no. 268/2006 (DCA).

This document was concluded for an initial period of 10 years, and after the expiry of this period, the Agreement will remain in force for as long as neither Party notifies in writing, one year in advance, its intention to terminate it.

In accordance with Art. I of the DCA, Romania makes available to US forces certain facilities and areas on the national territory in order to carry out the activities approved by the Agreement.

\footnotetext{
127 https://dpap.mapn.ro/app/webroot/fileslib/upload/files/Cooperare\%20militara\%20-\%20legi/Legea_2682006.pdf, accessed at 14 May 2021, 18: 30.
} 
The facilities and approved areas made available to US forces, as set out in Annex A to the DCA, are as follows:

- Smârdan training ground;

- Babadag training polygon and embarkation-disembarkation ramp;

- Mihail Kogălniceanu Air Base;

- Cincu training ground;

- The wider area of maneuvers includes areas in Constanța and Tulcea counties and is delimited by the town of Babadag to the north, the Babadag polygon to the east, Tariverde to the south and the commune of Horia to the west,

- any other facilities and areas of public property that would be agreed later, by agreement of the parties.

According to art. II of the DCA, the US forces will not have military bases installed on the territory of Romania, but will use the facilities and areas provided by the Romanian state "for the purpose of training, transit, support and related activities, refueling of aircraft, temporary maintenance of vehicles, ships and aircraft, accommodation of personnel, communications, stationing and deployment of forces and materials, prepositioning of defense equipment, goods and materials, and for other purposes that the designated parties or authorities may agree with them ", in full compliance with Romanian legislation. "Upon request, Romania shall assist in facilitating the temporary access of United States forces to publicly owned lands, including those controlled by municipalities, as well as to privately owned lands, for maneuvers and training of United States forces."

It should be mentioned that Romania retains its rights and property titles over the agreed facilities and areas made available to the US forces. In this regard, the United States forces will return to Romania any agreed facility or area, as well as any division thereof, once they are no longer needed.

Romania and the USA, through their designated authorities (United States Department of Defense and Romanian Ministry of National Defense) will consult on how to return any of the agreed facilities and areas, including possible compensation for construction or improvements performed.

The American forces deployed in Romania in the agreed facilities and areas are rotational forces, under the command of EUCOM.

In order to carry out the activities approved by the Agreement, Romania has the obligation, in accordance with art. III para. (1) of the DCA to provide the logistical support requested by US forces.

According to Annex B of the DCA, the following categories of logistical support are considered to be made available to US forces:

- accommodation;

- maintenance and repair services, including storage; drinking and nonpotable water, including distribution and storage; 
- food, perishable and non-perishable;

- fuel, including storage, distribution and quality control services; land, sea and air transport services;

- utilities and services, including energy and communications; - the need for civilian labor force;

- medical assistance and services;

- air services for aircraft and cargo;

- other appropriate forms of mutual assistance, as agreed.

\subsection{Romania's participation in the Missile Defense System}

Allied efforts to develop a NATO ballistic missile defense system (NATO BMD) are based on threats posed by the global proliferation of ballistic missiles.

Accelerating change in this area has led the Alliance to work to adapt and develop its position of deterrence and defense to cope with these developments. Thus, according to the Allied decision, the NATO BMD system is developed on two main components: a common command-control (C2) system, developed from common funds, and voluntary national contributions consisting of detection and interception systems, connected to the allied C2 system.

In 2012, missile defense gained a central position in NATO's revised deterrent and defense stance. The Allies pledged at the NATO Summit in Chicago to maintain an appropriate package of nuclear, conventional and anti-missile capabilities to fulfill NATO's core missions enshrined in the Strategic Concept.

Under these conditions, the BMD's capability has been defined as having a complementary role to deterring nuclear weapons, of a purely defensive nature, to deal with threats from outside the Euro-Atlantic area.

It was also stated on this occasion ${ }^{128}$ that the NATO BMD system is not directed against Russia and does not have the capacity to undermine Russia's strategic arsenal of deterrence. At the same time, NATO declared BMD NATO's Interim Missile Defense Capability, bringing together individual contributions under the command and control of the Alliance.

At the NATO Summit in Warsaw (2016), the NATO BMD's Initial Operational Capability (IOC) was declared. This strategic moment was facilitated by the completion and operationalization of the second phase of the European Phased Adaptive Approach (EPAA) project, namely the activation of the Aegis Ashore system in Deveselu, thus offering a significant increase in the ability to cover and protect the Allied territory against possible attacks with ballistic missiles, from outside the Euro-Atlantic space.

At the Brussels Summit (2018), the political principles underlying the development of NATO BMD capability were reaffirmed, as well as the

\footnotetext{
${ }^{128}$ Participarea României la Sistemul de apărare antirachetă, https://www.mae.ro/node/1517, accessed at 14 May 2021, 18: 30 .
} 
determination of allies to continue development in a rapid and efficient manner of the $\mathrm{C} 2$ system, on the completion of which depends achieving NATO's Full Operational Capability (FOC) of the BMD.

Through the EPAA, the United States makes the largest contribution to the NATO BMD. It is built with elements that can be integrated gradually, as it becomes operational.

As part of the voluntary national contributions, Romania participates, together with other allies (Poland, Spain and Turkey) in the development of the missile defense system in Europe, providing the location for hosting some of its essential components.

Thus, on September 13, 2011, Romania and the USA signed the Agreement on the location in Romania of the United States defense system against ballistic missiles (BMDA), ratified by Law no. 290/2011 $1^{129}$. It entered into force on 23 December 2011.

The main construction works at the Anti-Missile Facility within the Deveselu Military Base started on October 28, 2013 and the completion of the BMDA implementation framework ended on July 29, 2014. On December 18, 2015, the Technical Capacity of the Anti-Missile Facility was declared.

\subsection{Legal framework of the participation of the armed forces in missions and operations outside the territory of the Romanian State}

The constitutional provisions regulate the possibility of the participation of the armed forces in collective defense in military alliance systems and in actions regarding the maintenance or restoration of peace, under the conditions of the law and of the international treaties to which Romania is a party.

Thus, the provisions of Law no. 121/2011 $1^{130}$, the participation of the armed forces in missions and operations outside the territory of the Romanian state, with the subsequent completions, regulates the conditions in which the armed forces of Romania participate in missions and operations outside the territory of the Romanian state.

According to the provisions of Law no. 121/2011, the missions and operations in which the armed forces participate outside the territory of the Romanian state are:

- collective defense within the North Atlantic Treaty Organization or ensuring the security of the Member States of the European Union;

- implementing allied security measures, advanced presence and deterrence, as well as other actions established by North Atlantic Council decisions to

\footnotetext{
129 https://dpap.mapn.ro/app/webroot/fileslib/upload/files/Cooperare\%20militara\%20-\%20legi/Legea_2902011.pdf, accessed at 14 May 2021, 18: 50.

${ }^{130} \mathrm{https} / / /$ www.mapn.ro/legislatie/documente/L121.pdf, accessed at 16 May 2021,18: 50.
} 
ensure security in the North Atlantic area, in accordance with the provisions of the North Atlantic Treaty signed in Washington, on April 4, 1949;

- crisis response;

- peace;

- humanitarian assistance.

Until the entry into force of Law no. 121/2011, the legal framework of the participation of the Romanian armed forces in military exercises and actions outside the territory of the Romanian state was provided in the Law no. 45/1994 of the National Defense. According to Law no. 45/1994, for each participation of Romania with soldiers in missions outside the national territory, regardless of the type or duration of the mission, the number of participants, the approval of the Parliament had to be requested, at the proposal of the President of Romania, a procedure lasting approximately two months.

According to current regulations, the sending of armed forces outside the territory of the Romanian state in missions and operations carried out under the mandate of the United Nations or the Organization for Security and Cooperation in Europe, under the leadership of the North Atlantic Treaty Organization or the European Union, in coalitions and according to the obligations assumed by Romania through treaties, it is approved, at the proposal of the Prime Minister, by the President of Romania, after consulting the Supreme Council of National Defense.

In this respect, at the proposal of the Ministry of National Defense, the Supreme Council of National Defense analyzes and decides, until June 30 of each year, the armed forces that can be made available in the following year. The proposal to participate in missions and operations outside the territory of the Romanian state also includes the estimation of the afferent costs.

If the sending of the armed forces outside the territory of the Romanian state is not done on the basis of an international treaty to which Romania is a party, as well as if the sending is made at the request of a state, the President of Romania requests the approval of the Parliament.

According to the provisions of Law no. 121/2011, the Minister of National Defense has the competence to send in individual mission outside the national territory observers/monitors, military advisers and instructors, staff and specialized personnel, after prior consultation of the Ministry of Foreign Affairs, without exceeding the numerical limits of the package of forces approved annually by the Supreme Council of National Defense.

Also, the Minister of National Defense is empowered by law to approve the sending of the armed forces to exercises, trainings, ceremonies and other related activities organized outside the territory of the Romanian state.

The detailed elements regarding the participation of the armed forces in missions and operations within some international forces or within some units of other states are established by the specialized structures of the Ministry of 
National Defense by concluding technical agreements, according to the procedure of concluding technical agreements approved by Decision Government no. $1374 / 2004$.

In the content of Law no. 121/2011 other aspects are also established, such as:

- transfer of authority;

- selection, employment and some rights of staff;

- financial aspects regarding the participation of the armed forces in missions and operations outside the territory of the Romanian state;

- the acquisition of goods, works and services, outside the territory of the Romanian state, necessary for the fulfillment of missions and operations by the armed forces.

According to the provisions of art. 16 of Law 121/2011, the military and civilian personnel participating in missions and operations outside the territory of the Romanian state benefit, during their duration, from the following rights:

- an additional rest leave, of 2.5 days for each month of presence in the area of operations, with the possibility to be performed during the execution of the mission, in the country of deployment, in the deployment area or in Romania, depending on the security situation in the area;

- salary rights ensured according to the legal provisions in force;

- reimbursement of transport expenses for a trip to the country and back, every 6 months of participation in the mission or operation, except in cases where the expenses have been borne by the international bodies under whose auspices the mission or operation is performed.

The rights of daily allowance, accommodation, food, facilitating the connection with the family, recreation and transport of the military and civilian personnel participating in the missions and operations provided in Law no. 121/2011 are established by Government Decision no. 46/2020.

\section{Legal System, National Defense System and exceptional states}

According to art. 93 of the Constitution of Romania, the President "establishes, according to the law, the state of siege or state of emergency in the whole country or in some administrative-territorial units and requests the Parliament to approve the adopted measure, within 5 days from its adoption".

Also, if "Parliament is not in session, it shall be convened by law no later than 48 hours after the establishment of the state of siege or the state of emergency and shall function throughout their duration." This provision must be corroborated with the provisions of art. 100 of the Supreme Law, according to which in the exercise of his attributions, the President of Romania issues decrees that are published in the Official Gazette of Romania. Non-publication entails the non-existence of the decree. The decree must also be countersigned by the prime minister. It is interesting to note that neither the Constitution nor the Emergency 
Ordinance no. $1 / 1999$ on the state of siege and the state of emergency ${ }^{131}$ does not expressly provide powers to the Government during either state.

At the same time, the mentioned provisions do not establish the circumstances in which the state of emergency and the state of siege can be established, the organic law having to regulate their regime.

During the establishment of the two states, the Parliament is to function, as specified in the constitutional text. In the doctrine there is a debate in the sense that the Parliament is convened only to give an approval or to actively intervene in the creation of the rule of law.

The prevailing view is that Parliament must continue to function as a guarantee against any abuse and excess.

\subsection{Circumstances of the Emergency Ordinance No. 1/1999 on the regime of the state of siege and the regime of the state of emergency}

The regime of these exceptional states represents areas to which the Constitution has given a special significance, ordering that it is regulated by organic law. However, Emergency Ordinance no. 1/1999 was adopted by the Government in 1999. A particularly important normative act was adopted in one night, in the context of what has been called "Mineriade" since 1999. The protest of the miners in the Jiu Valley revealed the significance of the existence of legislation clear and coherent, in a very sensitive area.

\subsubsection{Military authorities and state of emergency or siege}

According to the Emergency Ordinance no. 1/1999, when establishing the state of siege or the state of emergency, some attributions of the specialized central public administration and of the local public administration fall within the competence of the military authorities and other public authorities, provided in the decree establishing the state of siege or expedite. At first sight, it is clear that the issue of the powers of the military and civilian authorities is confusing and imprecise, as there is a clear distinction between them, as set out below.

\subsection{Responsibilities of military authorities during a state of emergency or siege}

According to the provisions of the Emergency Ordinance no. 1/1999, as well as in the decree establishing the state of siege or the state of emergency, the military authorities, as well as the other public authorities provided in art. 7 para. (1) have the following attributions and responsibilities:

a) to draw up action plans and plans for the gradual lifting of combat capability, in accordance with its own orders and instructions;

b) to order the temporary deposit, at the police bodies within the county or of the Bucharest municipality, of the weapons, ammunition and explosive

\footnotetext{
${ }^{131} \mathrm{http} / / /$ legislatie.just.ro/Public/DetaliiDocument/16739, accessed at 16 May 2021, 19: 50.
} 
materials found on the population and to proceed to the search of those not deposited within the established term, following the cessation of the exceptional measure returned to those entitled to own them; to order the temporary closure of companies trading in weapons and ammunition and to establish their security;

c) to limit or prohibit the movement of vehicles or persons in certain areas or between certain hours and to issue, in justified cases, permits for free movement;

d) to carry out controls on certain persons or places, when they are required;

e) to carry out raids;

f) to exercise exclusively the right to authorize the holding of public assemblies, demonstrations or marches;

g) to evacuate from the area subject to the state of siege or emergency the persons whose presence is not justified;

h) to direct the evacuated or refugee persons on the directions and in the established areas and to keep their records;

i) to protect military information intended to be communicated through the media; information on the state of siege or the state of emergency, with the exception of those relating to disasters, shall be made public only with the approval of the military authorities; the mass media, regardless of the nature and form of ownership, are obliged to transmit, with priority, the messages of the military authorities, at their request;

j) to order the temporary closure of some fuel distribution stations, of some restaurants, cafes, clubs, casinos, headquarters of the associations and of other public places;

k) to temporarily suspend the appearance or broadcasting of some publications or of some broadcasts of radio or television stations;

1) to ensure the military security of the water supply, energy, gas stations, of the headquarters of the public broadcasting and television stations, of the economic operators that have capacities of strategic importance at national level, as well as of the objectives of special importance for defense, by implementing the Plan for the mobilization of the national economy for defense; when the situation requires, order the temporary shutdown of the gas, energy and drinking water supply, as the case may be;

m) to order the rationalization of food and other products of strict necessity;

n) to issue military ordinances or orders, as the case may be;

o) to prohibit road, rail, sea, river and air traffic on different routes.

Consequently, when we study the responsibilities of the civilian authorities that are transmitted to the military authorities, except for those provided in let. a), i) and $n$ ) it can be concluded that all other attributions pass from the military authority to the civilian one. 


\subsection{Military ordinances ${ }^{132}$}

The practice of military ordinances begins somewhere in Romania's past, the first normative act in which the possibility of using this legal instrument was identified, dating from 1864 in the Law on the state of siege.

We appreciate that, in the current era, given that military ordinances belong to a turbulent time, by law ferenda should be considered mechanisms to regulate such states (emergency and siege) more flexible, more adapted to the 3rd millennium, by to ensure legal order and efficiency.

Another inconvenience that we identify consists in the fact that the name of military ordinance is likely to create confusion, considering that, in the Constitution of Romania, other types of normative acts are regulated with the name of ordinances.

According to art. 73 of the Constitution of Romania, the two states (emergency and siege) are established by organic law. However, the Government issued in 1999 an emergency ordinance approved by the Parliament only in 2004, by Law no. 453 approving the Emergency Ordinance no. 1/1999.

Subsequent amendments to this normative act, especially those of Law no. $453 / 2004$, also mitigated from the initial problems of the normative act. It was introduced, among others, a new paragraph (4) in art. 18.

The fact that it was provided in the Emergency Ordinance no. 1/1999 that, in a state of emergency, the forces of the Ministry of National Defense may provide support to the forces of the Ministry of Internal Affairs, based on the approval of the Supreme Council of National Defense, within the limits and conditions established by it but only in missions for which they have the appropriate training and equipment, is likely to lead to the clarification of the situations in which the army can act and, at the same time, the possibility of intervening in public order missions, missions that are not specific to it, is far removed.

\subsection{Conclusions about legislation regarding regulatory acts of exceptional states}

The regulation of the state of emergency and the state of siege should set out in a concrete and detailed manner the tasks of the armed forces. Their attributions must be rigorously formulated and be exclusively limited to the relevant constitutional provisions. According to the provisions of Law no. 346/2006 on the organization and functioning of the Ministry of National Defense, this is the specialized body of the central public administration, which leads and carries out, according to the law, the activities in the field of defense of the country.

\footnotetext{
132 Art. 20 lit. n din Ordonanţa de urgenţă nr. 1/1999, http://legislatie.just.ro/Public/DetaliiDocument/16739, accessed at 16 Mai 2021, 18.50.
} 
Therefore, the defense of the country is the fundamental duty of the Ministry of National Defense, meaning that, in fact, the training of the army is carried out. Carrying out public order missions or other types of missions that exceed its duties implies, among other things, that, if it acts, it will do so without having the necessary training and means, with all the implicit risks and shortcomings.

If the army deals with national defense, the Ministry of Internal Affairs, through various structures, has responsibilities aimed at public order.

According to Law no. 218/2002 on the organization and functioning of the Romanian Police, it "is part of the Ministry of Internal Affairs and is the specialized institution of the state, which exercises attributions regarding the protection of rights and freedoms fundamental rights of the person, of private and public property, prevention and detection of crimes, observance of public order and tranquility".

The Gendarmerie also plays an important role in defending fundamental values within the state. According to Law no. 550/2004 on the organization and functioning of the Romanian Gendarmerie, this is "the specialized institution of the state, with military status, component of the Ministry of Administration and Interior, which exercises, under the law, its attributions regarding the defense of public order and peace, the fundamental rights and freedoms of citizens, public and private property, the prevention and detection of crime and other violations of the laws in force, as well as the protection of fundamental state institutions and the fight against acts of terrorism".

Also, the Romanian Gendarmerie, through attributions, organization, training and territorial disposition, contributes to guaranteeing the sovereignty, independence, authority, unity and security of the state, constitutional democracy on the entire national territory both in peacetime and in crisis situations.

In the Practical Guide for parliamentarians no. 5/2003, in section II, Parliamentary control of the security sector, published by the Inter-Parliamentary Union and the Center for Democratic Control of the Armed Forces, Geneva, after emphasizing that it is not desirable for the army to be involved in maintaining public order, points out that, in principle, if there is no other solution, Parliament must ensure that the involvement of the armed forces in maintaining law and order is clearly defined, restricted and regulated by law, including:

- the circumstances in which the army may be used;

- the nature and limits of its involvement;

- duration of involvement;

- the types of units that may be involved in each case;

- the institutions empowered to make the decision to involve the army and to interrupt the involvement;

- competent jurisdiction in case of human rights violations. 


\section{BIBLIOGRAPHY}

- Agreement between Romania and the United States of America on the activities of United States forces stationed in Romania, signed in Bucharest on December 6, 2005.

- Agreement on the location in Romania of the United States Ballistic Missile Defense System (BMDA).

- Carta alba a apărării 2021.

- The Constitution of Romania, republished.

- Drăguț M., International Law. The legal status of the foreign armed forces on the Romanian territory, C.H. Beck, Bucharest, 2009.

- Întrebări şi răspunsuri privind participarea României la sistemul de apărare antirachetă al SUA, https://www.mae.ro/node/1523.

- Law no. 45/1994 of the national defense of Romania, with subsequent amendments and completions.

- Law no. 203/2015 on defense planning and national defense strategy.

- Law no. 415/2002 on the organization and functioning of the Supreme Council of National Defense.

- Law no. 291/2007 on the entry, stationing, conduct of operations or transit of foreign armed forces on the territory of Romania.

- Law no. 121/2011 on the participation of the armed forces in missions and operations outside the territory of the Romanian state.

- Moştoflei C., Duțu P., Național și colectiv în apărarea României, Editura Universităţii Naţionale de Apărare „Carol I” Bucureşti, 2007.

- https://cssas.unap.ro/ro/pdf_studii/national_si_colectiv_in_apararea_romaniei.pdf

- https://www.mae.ro/node/1517. 